\title{
O Direito de Subscrição em Aumento de Capital, no Fideicomisso Acionário
}

\author{
Fábio Konder Comparato \\ Professor Titular da Faculdade de Direito da \\ Doutor em Direito da Universidade de Paris
}

\section{Introdução}

$\mathrm{Na}$ história do direito privado ocidental, a instituição fideicomissária aparece marcada por disputas constantes. A polêmica em torno do instituto, na verdade, não data apenas da Revolução Francesa e da abolição da ordem feudal. Já em 1560, a ordenação francesa dita de Orléans proibia o fideicomisso além do segundo grau. Em 1730, o chanceler DAGUESSEA0, que obteria dezessete anos depois, com outra ordenação, a reafirmação das restrições de Orléans, escrevia que "a revogação completa dos fideicomissos seria, talvez, a melhor de todas as leis".

O Código Napoleão, como sabido, veio - muito embora não tão direta e completamente como soa o texto de seu art. 896 - atender aos reclamos do velho ministro de Luís XV, declarando nula toute disposition par laquelle le donataire, l'héritier institué ou le légataire sera chargé de conserver et de rendre à un tiers, nulidade essa extensiva à própria relação entre qualquer desses fiduciários e os bens fideicomitidos. BIGoT DE PRÉAMeneu, na exposição de motivos do Código, entre outras razões dessa proibição, apontou-lhe a principal: nas famílias opulentas, escreveu, as instituições fideicomissárias, tendo por escopo concentrar os bens nas mãos de um só de seus membros, esbulhando os outros, originam graves discórdias e processos constantes. Essa litigiosidade do fideicomisso, de resto, já fora assinalada por MoNTESQUIEU, insuspeito para tanto, pois sustentava a importância do instituto como esteio da nobreza nos regimes monárquicos. Le retrait lignager, reconheceu, fait une infinité de procès nécessaires ${ }^{1}$.

1. De l'Esprit des Lois, livro V, cap. IX, éd. Garnier, t. I, Paris, 1973, pág. 63. 
A multiplicação de processos judiciais, oriundos de um mesmo instituto, constitui seguro sintoma de sua deficiente estrutura interna ou de seu desajustamento às funções que deve exercer na vida social. No caso do fideicomisso, o diagnóstico parece se concentrar mais nessa última causa. Com efeito, desde o direito romano a instituição fideicomissária tem servido, de modo constante, a um resultado indireto, nem sempre coincidente com a finalidade aparente de suas regras. Em Roma, tratava-se de contornar o rígido sistema de incapacidades sucessorais, que atingia as mulheres, os furiosi e os peregrini. Desde logo, porém, percebeu-se que o mecanismo fideicomissário redundava em um reforço, sem contrapartida, do patrimônio dos fiduciários, os quais, muita vez, recusavam-se, pura e simplesmente, a devolver os bens recebidos. Daí passar-se, de um sistema de mera confiança ou simples pedidos ( $a b$ aliquo petere, aliquem rogare), a fórmula de autêntica constrição judicial, no processo extra ordinem, a partir de Augusto ${ }^{2}$. No sistema aristocrático-fundiário, a vontade do testador, perdurando por gerações sucessivas, acabava criando uma linha sucessoral própria, em substituição à da lei, como se disse no preâmbulo da ordenação francesa de 1747; sistema esse que, pelas suas evidentes implicações públicas, redundava numa forma privada de regulação do poder político. Assim, quando o discours préliminaire do Código Civil francês profligou "essas substituições absurdas", qui subordonnent les intérêts du peuple vivant aux intérêts du peuple mort, et dans lesquelles, par la volonté de la génération qui n'est plus, la génération qui est se trouve sacrifiée à celle qui n'est point encore, os interesses visados não eram exatamente la liberté de la circulation ou le bien de l'agriculture, como lá se disse. Ou, pelo menos, o que estava em jogo somente em primeira análise se identificava com a livre exploração e circulação dos bens imóveis. $\mathrm{Na}$ verdade, a ruína política da aristocracia, diante da ascensão burguesa, teria que consumar-se com a supressão dessa base fundiária, sobre a qual se estabeleceram a fortuna e o poder político dos nobres. A instituição fideicomissária, como observou um autor, tornando os bens fideicomitidos inalienáveis em mãos do fiduciário, forçava-o, de certo modo, a permanecer rico malgré lui ${ }^{3}$. Não apenas rico, mas politicamente pode-

2." cf. Vincenzo Arangio, Ruiz, Istituzioni di Diritto Romano, Nápoles (Casa Editrice Dott. Eugenio Jovene), 1976, pág. 573.

3. Lefebvre, citado por Georges Ripert e JeAn Boulanger, no Traité de Droit Civil d'après le Traité de Planiol, t. IV, Paris (Librairie Générale de Droit et de Jurisprundènce), $1959, \mathrm{n} .^{\circ} 3.860$. 
roso. Suprimidas essas muletas legais da aristocracia, a terra e com ela o poder viriam, naturalmente, às mãos dos que tinham o dinheiro em lugar de títulos nobiliárquicos.

Percebe-se, pois, que a razão dessa excessiva litigiosidade do fideicomisso residia, como ainda reside, no fato de que a instituição tem servido, através dos séculos, a conservar o poder (econômico ou político) em determinada linha sucessoral, abolindo-se, quanto a essa realidade do comando (apesar da alienabilidade individual dos bens componentes da massa hereditária), a possibilidade jurídica de disposição por parte do herdeiro ou legatário. $E$ não há nada que os homens possuam mais zelosa e ciumentamente que o poder. O fiduciário, que o recebe desde logo, com a abertura da sucessão do testador, raramente se conforma com a impossibilidade de instituir $o$ seu próprio sucessor, e porfia em descobrir, por meios indiretos, uma saída para a resolubilidade do domínio. O fideicomissário, por sua vez, impacienta-se com a dilação imposta ao exercício de seus direitos sucessórios e tende, facilmente, a indispor-se com os que detêm, temporariamente embora, a sua propriedade.

Quer dizer-se, então, dessa forma moderna de dominação, que é o poder de controle empresarial, representado por um pacote acionário? Como desconhecer que é, doravante, em torno dele, como outrora o foi a respeito da propriedade fundiária, que se ferem os grandes conflitos de poder econômico, com repercussões freqüentes no terreno político?

O grau de litigiosidade da instituição fideicomissária avulta de tomo, certamente, quando aplicada ao controle acionário de companhias ou grupos societários. Pois as ações de sociedade anônima não são bens iguais aos que, tradicionalmente, constituiam objeto de propriedade. AsCARELLI denominava as ações de companhias "bens de segundo grau", porque se referem, sempre, a elementos componentes de outro patrimônio ${ }^{4}$. Mais do que isso, diríamos nós, referem-se a uma organização econômica de pessoas e bens, destinada à produção, circulação de mercadorias ou prestação de serviços no mercado, com intuito lucrativo. As ações de sociedade anônima, em uma palavra, dizem respeito à empresa. Assim, não se trata de bens possuídos ou usufruídos por si mesmos, mas como instrumento, veículo ou título de legitimação à posse, usufruto ou disposição de outros bens, componentes do patrimônio social. Tratando-se de um bloco de controle acionário, o direito real sobre os títulos

4. cf. o ensaio Riflessioni in tema di titoli azionari e società tra società, in Saggi di Diritto Commerciale, Milão (Giuffrè), 1955, págs. 228 e segs. 
atribui a legitimidade do poder de comando sobre a empresa, no seu conjunto de pessoas e bens. $\mathrm{E}$ se, por hipótese, as ações em causa representam o controle de uma sociedade matriz de grupo econômico, com sociedades controladas em cadeia, ou coligadas em leque, aqueles títulos constituirão bens de graus sucessivos, correspondentes ao encadeamento societário.

É por esta razão que um estudo sobre o fideicomisso acionário, especialmente ligado à questão do direito de subscrição de novas ações, não pode deixar de se iniciar por uma análise desse último direito, à luz dos elementos e princípios que regem as relações jurídicas sobre títulos acionários.

\section{O Direito de Subscrição de Ações em Aumento de Capital}

A lei brasileira, desde 1940, fala em "direito de preferência" do acionista à subscrição de novas ações a serem emitidas em aumento de capital. A expressão é tecnicamente deficiente, pois não se trata de simples prelação ou preferência e, sim, de autêntica opção ${ }^{5}$. Deliberado o aumento de capital por subscrição, os acionistas não ficam submetidos à concorrência de ofertas, mas gozam de um direito exclusivo durante o prazo fixado pelo estatuto ou pela assembléia, prazo esse que não poderá ser inferior a trinta dias (Lei n. ${ }^{\circ} 6.404$, de 1976, art. $171, \S 4 .^{\circ}$ ). De sorte que a companhia não pode aceitar ofertas de subscrição de terceiros, durante esse prazo, ainda que em condições econômicas mais vantajosas que as estatuídas para os acionistas.

Por aí se revela a natureza desse direito de opção do acionista como verdadeiro poder, categoria de direito subjetivo que confere ao seu titular a prerrogativa de atuar, unilateralmente, sobre a esfera jurídica alheia. Mais precisamente, trata-se de um poder de criar relação jurídica, um "direito formador" (Gestaltungsrecht), segundo a doutrina germânica "

5. Sobre o assunto, sic Pontes De Miranda, "Tratado de Direito Privado", 3. ${ }^{a}$ ed., t. 50, Rio de Janeiro (Borsoi), 1972, §5.329, 5, “b", págs. 356 e 357 ; no direito italiano, GIANCARLo Frè, Società per Azioni, in Commentario del Codice Civile a cura di A. Scialoja e G. Branca, 4. ${ }^{2}$ ed., Bolonha (Zanichelli) e Roma (Foro Italiano), 1972, pág. 734.

6. cf. KARL LARENZ, Allgemeiner Teil des deutschen bürgerlichen Rechts, Munique (Beck'sche Verlagsbuchhandlung), 1967, págs. 233/4, frisando que a opção é um protótipo de "direito formador"; ANDREas von TuHR, Partie Générale du Code Fédéral des Obligations, trad. de Maurice de Torrenté e Emile Thilo, 2. ed., Lausanne (Imprimerie Centrale), 1933, vol. I, § 3; HALUK TANDogaN, Notions Préliminaires à la Théorie Générale des Obligations, Genebra (Librairie de l'Université), 1972, págs. 37 segs. 
ou "direito potestativo" 7 de acordo com os autores italianos. Ao exercer a opção de subscrição, o acionista faz atuar a deliberação autorizadora do aumento de capital social pela assembléia e, portanto, interfere na estrutura patrimonial da pessoa jurídica. Ele não tem, no caso, simples direito subjetivo a uma prestação da companhia, como, por exemplo, em matéria de dividendo. Perante o acionista que exerce a opção de subscrição, a sociedade anônima se encontra na situação passiva denominada sujeição ${ }^{8}$, tendo que suportar, em seu patrimônio, os efeitos jurídicos do exercício do poder pelo subscritor.

Se a lei modelou essa prerrogativa acionária de forma tão robusta, como poder jurídico e não como direito a uma prestação da companhia, e se o legislador atribui-lhe, tradicionalmente, a eminência de "direito essencial do acionista" (Lei n. ${ }^{\circ}$ 6.404, art. 109, IV), é porque a sua função deve aparecer como primordial na economia societária. $\mathrm{E}$, de fato, o direito de opção à subscrição de novas ações de aumento de capital constitui elemento indispensável à preservação do status ou posição jurídica do acionista na companhia. Esse status, como sabido, compreende, do lado ativo, tanto direitos patrimoniais quanto direitos políticos, isto é, de participação no governo social e fiscalização da atividade administrativa. Uns e outros acham-se diretamente ligados à posição acionária no capital da companhia. De acordo com o princípio capitalístico, rigorosamente seguido na sociedade anônima, o status socii é determinado pelo número de ações possuídas, em relação à totalidade da mesma espécie de ações em que se divide o capital social.

Assim, no tocante à situação patrimonial do acionista, se não se lhe desse o direito potestativo de participar dos aumentos de capital deliberados, atribuindo-se a terceiros as novas ações emitidas, o acionista veria reduzida a sua quota-parte na distribuição de dividendos, quando em funcionamento a companhia, ou na distribuição do acervo líquido social, no caso de liquidação da sociedade. Conseqüentemente, o valor do seu pacote acionário ver-se-ia igualmente reduzido. Deve-se observar, aliás,

7. cf. G. AuletTa, Poteri formativi e diritti potestativi, in Rivista di Diritto Commerciale e del Diritto Generale delle Obbligazioni, 1939, I, p. 557; Puleo, I Diritti Potestativi, Milão (Giuffrè), 1959.

8. Esse conceito, correlato ao de poder jurídico ou direito potestativo, foi elaborado pela primeira vez por G. ChIOvenda, em seu famoso estudo de 1903 L'azione nel sistema dei diritti, e retomado em seguida pelos escritores alemães com o termo de Bindung (cf. K. Larenz, op. cit., págs. 84/85). Carnelutti (Teoria Generale del Diritto, 3. a ed., Roma, Foro Italiano, 1951, págs. 168 e segs.) distingue, claramente, a sujeição, tanto do dever, quanto do ônus. 
que as participações nos lucros sociais ou no acervo líquido, no caso de liquidação da companhia, constituem outros tantos "direitos essenciais" do acionista, os quais só se garantem, plenamente, com o respeito ao direito de opção à subscrição de ações, em aumento de capital.

Ressalte-se, ademais, que toda emissão nova de ações seja com ingresso de novos recursos na companhia, seja com a capitalização de reservas e lucros, ou com a reavaliação de ativos - acarreta, em princípio, uma pressão baixista na cotação das ações no mercado, pelo acréscimo de oferta desses papéis em relação à demanda existente. Por conseguinte, a aquisição das ações de nova emissão deve representar, para o acionista, uma forma de compensação pela perda, ainda que momentânea, do valor do seu investimento acionário primitivo, no mercado.

Mas é, sem dúvida, quanto à preservação dos chamados direitos políticos do acionista que a garantia representada pelo direito de opção à subscrição de novas ações aparece em toda a sua plenitude. É que, de um lado, há minorias qualificadas para o exercício de certos poderes na companhia; de outro, há o controle acionário, definido como a titularidade de ações, que assegura, de modo permanente, a maioria dos votos nas deliberações da assembléia geral e o poder de eleger a maioria dos administradores sociais (art. 116).

As hipóteses de minoria qualificada são as mais variadas, no sistema legal. Acionista ou acionistas, representando 0,5\% (meio por cento) ou mais do capital social, têm o direito de obter relação de endereços dos acionistas aos quais a companhia enviou pedidos de procuração, para o fim de remeter novo pedido (art. 126, $\S 30^{\circ}$ ). Titulares de $5 \%$ (cinco por cento), pelo menos, do capital social, têm direito a pedir, judicialmente, a exibição por inteiro dos livros da companhia, nas hipóteses previstas no art. 105. Com a titularidade de ações representando igual percentagem do capital, é também facultado ao acionista : a) propor a ação social de responsabilidade uti singuli contra os administradores, se a assembléia deliberar não promover a ação (art. 159, $\S 4^{\circ}$ ) ; b) obter do conselho fiscal informações sobre matérias de sua competência (art. 163, § $\left.6 .^{\circ}\right)$; c) propor a ação de dissolução da companhia que não puder preencher o seu fim (art. 206, II, "b") ; d) propor a ação social uti singuli de perdas e danos contra a sociedade controladora pelos danos causados à companhia controlada, por abuso de poder (art. 246, § 1.0, "a"). Com 5\% (cinco por cento) do capital sem direito a voto, ou $10 \%$ (dez por cento) 
do capital votante, tem o acionista o direito potestativo de obter a instalação do conselho fiscal, nas companhias em que o seu funcionamento não for permanente (art. 161, § 2. ${ }^{\circ}$ ). Com $5 \%$ (cinco por cento) do capital votante, podem os acionistas convocar a assembléia geral, quando os administradores não atenderem, no prazo de oito dias, ao seu pedido de convocação (art. 123, parágrafo único, "c"). Com 10\% (dez por cento) do capital votante, podem: a) requerer a adoção do processo de voto múltiplo, para a eleição dos membros do conselho de administração (art. 141) ; b) eleger, em votação em separado, um membro do conselho fiscal e respectivo suplente (art. 161, § 4. , "a").

Imagine-se o que representaria, para um acionista titular de alguma dessas posições de minoria qualificada, à falta do direito individual de opção, a impossibilidade de participar de aumento de capital deliberado pelo controlador, resignando-se, assim, a perder a percentagem acionária que lhe dava o poder de intervir na vida social, ou de fiscalizar, de modo especial, a gestão administrativa.

Mas o reverso da medalha deve, também, ser considerado. A ausência do direito de opção, como prerrogativa essencial do acionista, poderia levar o controlador a perder o controle, em razão de manobras especiosas utilizadas por outros acionistas, ou por titulares de direito real (usufruto ou caução, por exemplo) sobre as ações, por ocasião de aumentos de capital.

Não se pode, pois, desconsiderar a importância desse direito essencial, como meio de preservação do status do acionista. É dessa sua função primordial na economia da sociedade anônima que decorre o seu valor no mercado.

O direito de opção, de fato, é negociado - em Bolsa ou em balcão -, como valor mobiliário distinto da ação que lhe deu origem, com fundamento em sua livre cessibilidade (Lei n. ${ }^{\circ} 6.404$, art. $\left.171, \S 6 .^{\circ}\right)$. Na determinação de seu valor, leva-se em consideração, em primeiro lugar, o sobrevalor do patrimônio líquido da companhia, relativamente ao capital social. E a razão é simples: o terceiro que venha, eventualmente, a subscrever novas ações emitidas pela companhia, adquire o direito de participar desse sobrevalor - constituído de reservas acumuladas e lucros em suspenso - já formado anteriormente. Nada mais justo, portanto, que esse novo acionista pague aos antigos sócios, sob a forma de preço de cessão do direito de opção, ou à própria companhia, sob a forma de ágio, o montante correspondente a essa mais-valia acionária. 
No lançamento de novas ações à subscrição, a companhia não pode deixar de levar em conta o sobrevalor do patrimônio líquido em relação ao capital social, para a fixação do preço de emissão. Caso contrário, isto é, se vier a estabelecer esse preço muito abaixo do valor patrimonial da ação, estará praticando o que a técnica mercadológica denomina "diluição" do capital acionário ${ }^{\circ}$. 0 prejuízo conseqüente é duplo: para a própria companhia e para seus acionistas. Para a sociedade anônima, em primeiro lugar, porque ela deixa de recolher, pelas ações emitidas, todos os recursos de capital (no sentido largo), que poderia receber; o que significa que perde substância econômica, de certa maneira. Para os acionistas, em segundo lugar, porque o lançamento de novas ações a preço reduzido acarreta a inevitável baixa de cotação das antigas ações, reforçando-se a tendência depressora do seu valor venal, com o afluxo de novos papéis no mercado, como assinalado acima. Essa a razão da norma constante do art. $170, \S 1 .^{\circ}$ da lei de sociedades por ações.

Mas, na verdade, o valor econômico do chamado "direito de preferência" não se mede, apenas, pelo excedente do patrimônio líquido da companhia em relação ao montante do capital social; da mesma forma que o direito de opção não visa a proteger, tão-só, os direitos patrimoniais do acionista, mas também os seus direitos políticos. Toda empresa, enquanto going concern, como dizem os norte-americanos, possui um certo número de elementos de valor econômico que não se traduzem na contabilidade: cartas-patentes de funcionamento, autorizações administrativas, reservas ocultas do imobilizado, posição privilegiada no mercado por razões históricas ou meramente conjunturais. São os chamados "valores intangíveis", que geralmente se avaliam tão-só por ocasião dos negócios de cessão de controle (veja-se o art. 255, § $10^{\circ}$ da Lei n. ${ }^{\circ} 6.404$ ). Ademais, tais sejam as circunstâncias, o que pode estar em jogo, na cessão de direitos de opção à subscrição de novas ações, é a aquisição ou a perda de uma posição de minoria qualificada na companhia, atribuindo certos poderes de interferência na vida social, como explicado linhas atrás. $\mathrm{E}$ isto não pode deixar de ter o seu valor específico, no mundo dos negócios.

Chegamos, assim, naturalmente, à questão da qualificação do direito de subscrição do acionista, relativamente às ações

9. Watering, nos Estados Unidos; dilution, na França; Verwâsserung, na Alemanha; annacquamento, na Itália. 
das quais se origina. Que estas sejam a coisa principal e aquele a acessória, segundo a conceituação do Código Civil brasileiro (art. 58), não parece haver dúvida. O direito de opção à subscrição de ações em aumento de capital supõe a existência de ações primitivas, das quais exsurge ou deriva, pela boa razão de que se trata de um direito próprio de acionista. Mais do que isso: ele adere às ações, enquanto valores mobiliários autônomos, e não à pessoa de seu titular, por isso que pode ser livremente cedido (Lei n. ${ }^{\circ} 6.404$, art. 171, § 6..$^{\circ}$ ), salvo estipulação em contrário no estatuto, em acordo de acionistas ou negócio particular.

A questão fundamental não é essa e, sim, a de se saber que tipo de coisa acessória é o direito de subscrição, em relação às ações de onde provém.

o Código Civil enumera, na classe das coisas acessórias, os frutos, produtos e rendimentos (art. 60). A enumeração é, em parte, redundante, pois como salienta CLóvis ${ }^{10}$ os rendimentos nada mais são do que os chamados "frutos civis". Por outro lado, o elenco das coisas acessórias do art. 60 não deve ser tomado como exaustivo, faltando, por exemplo, a indicação das benfeitorias, reguladas nos arts. 62 e seguintes.

Fruto é todo bem ou utilidade que provêm de uma coisa, sem lhe alterar a substância. Na definição de fruto, é perfeitamente dispensável a referência à periodicidade de sua proveniência ${ }^{11}$, elemento, aliás, ausente da definição dada pelos melhores modelos legislativos, como o Código Civil alemão (\$ 99) e o italiano (art. 820). Essencial, no entanto, é que esse bem ou utilidade proveniente da coisa frutífera não lhe acarrete, pela sua separação, uma diminuição da substância. A colheita do café não importa alteração substancial dos cafeeiros. A percepção dos juros não implica redução do capital.

Quando, ao contrário, a separação ou retirada dos bens acessórios acarreta redução na quantidade ou valor da coisa de onde provêm, fala-se em produtos e não em frutos. É o exemplo clássico do mineral extraído da mina ou da pedra retirada da pedreira. $O$ que distingue os frutos dos produtos é, pois, a sua possibilidade de reprodução, seja pelas próprias forças da natureza, seja por obra do homem.

10. "Código Civil dos Estados Unidos do Brasil Comentado", vol. I (Livraria Francisco Alves), 11. ${ }^{a}$ ed., 1956, pág. 234).

11. sic, Pontes De Miranda, "Tratado de Direito Privado", cit., t. II, $\S 140$, I, pág. 76 . 
Ora, o direito de opção do acionista à subscrição de novas ações de aumento de capital não é um fruto das ações por ele já possuídas. $O$ acionista não os percebe como bem reprodutível sem diminuição do capital acionário, à maneira dos dividendos. Ao contrário, tendo em vista a sua função jurídica já longamente explanada, o direito de subscrição do acionista é elemento integrante do capital acionário, é parte de sua substância; de tal forma que, não exercida a opção de subscrever, a posição jurídica do acionista vê-se reduzida em quantidade e valor. Nem é por outra razão, de resto, que a cotação desse direito no mercado, quando destacado da ação que lhe deu origem, se estabelece, entre outros elementos, pelo montante das reservas acumuladas e lucros em suspenso no patrimônio da companhia; isto é, pelo sobrevalor patrimonial das ações, relativamente à sua expressão monetária, como fração-alíquota do capital social. Sob esse aspecto ${ }^{12}$, não há diferença substancial entre o direito de subscrição e as ações ditas bonificadas, porque provenientes da capitalização de reservas ou lucros.

Pode-se, hoje, dizer que já se estabeleceu o mais largo consenso doutrinário a respeito. "O direito de opção dos acionistas", escreveu PonTES DE MIRANDA, "não é fruto, mas é direito que se irradia das ações" ${ }^{13}$. Il diritto di opzione, afirmou ASCARELLI, non costituisce un frutto o una utilità derivata dalle vecchie azioni. Costituisce un diritto "ab origine" inerente alle vecchie azioni $e$ volto a impedire che il valore di queste possa risultare pregiudicato attraverso un aumento di capitale che permetta a terzi (senza sufficiente tutela dell'azionista) o a qualcuno solamente tra gli azionisti di passare a partecipare di quella differenza tra patrimonio e capitale sociale cui, in forza delle vecchie azioni, partecipava ogni azionista ${ }^{14}$. No tratado de RIPERT, editado por RoBLOT, lê-se: Le droit de souscription est un droit mobilier qui se sépare de l'action, mais qui est cependant un complément du droit constaté par l'action. L'action ancienne baissera de valeur à la cote de la bourse après l'augmentation de capital. Il faut donc considérer ce droit, non pas comme un fruit de l'action, mais comme un capital ${ }^{15}$. Na Alemanha Federal, a jurisprudên-

12. cf. A. SÁnchez Andrés, El Derecho de Suscripción Preferente del Accionista, Madrid (Civitas), 1973, págs. 147 e segs.

13. Tratado de Direito Privado, cit., t. L, $\$ 5.329$, 5, pág. 361 .

14. Diritto di Opzione e Usufrutto di Azioni, in Studi in Tema di Societa, Milão (Giuffrè), 1952, pág. 266.

15. Traité Elémentaire de Droit Commercial, $9 .^{2}$ ed., t. I, Paris (Librairie Générale de Droit et de Jurisprudence), 1977, n. ${ }^{\circ} 1553$. 
cia, segundo informa o clássico comentário de PALANDT ao Código Civil ${ }^{16}$, pronunciou-se no sentido de denegar ao direito de subscrição a natureza de fruto das ações de onde provém. Na expressão de SÁNCHEZ ANDRÉS, el derecho de suscripción se presenta asi como un valor substantivo quie forma parte del contenido económico de la participación social, que potencia el valor de la aportación originaria y cumple un papel de elemento reintegrador cuando aquella participación se fracciona ${ }^{17}$

Não se trata, pois, de fruto nem de produto e sim de um acréscimo (incrementum), que sobrevém às ações como parte acessória reprodutível do capital, cujo destaque deste reduz-lhe a substância ${ }^{18}$.

Analisado, assim, o primeiro elemento da dupla temática proposta, cuidemos agora de examinar o segundo, isto é, a instituição fideicomissária, antes de os combinarmos de forma harmônica, em busca do resultado almejado: a extensão, ou não, do fideicomisso às novas ações subscritas pelo fiduciário, no exercício da opção legal.

\section{O Fideicomisso}

A inclusão do fideicomisso no capítulo das substituições foi, sem dúvida, uma falha técnica do nosso Código Civil, como salienta PoNTES DE MIRANDA ${ }^{19}$. O fideicomissário não vem à sucessão em lugar do fiduciário. Ele sucede diretamente o testador, muito embora a herança só lhe seja devolvida após a morte do fiduciário, ou a certo tempo. Os que sustentam que o fideicomissário é sucessor do fiduciário, na verdade, confundem o fato de alguém ser titular de um bem (ou patrimônio) com o fato de esse titular não poder, temporariamente, exercer os direitos e adimplir as obrigações inerentes a esse patrimônio. Fala-se, também erroneamente, em "herdeiro condicional", seguindo-se os dizeres do art. 1.733 do Código ("sob certa condição"), mas condição propriamente não há; a não ser,

16. Palandt Bügerliches Gesetzbuch, $37 .^{\mathrm{a}}$ ed., Munique (C. H. Beck'sche Verlagsbuchhandlung), 1978, pág. 64.

17. op. cit., pág. 149 .

18. Sobre a categoria dos acréscimos, ainda pouco elaborada na teoria geral do Direito, cf. a rápida alusão que faz Clóvis Bevilaqua em sua "Teoria Geral do Direito Civil", revista e atualizada por Caio Mario da Silva Pereira, 2: ${ }^{\text {a }}$ ed., Rio de Janeiro (Livraria Francisco Alves), 1976, págs. 190/191.

19. “Tratado de Direito Privado", cit., t. LVIII, § 5.820; § 5.833, 1, 9 e $10 ; \S 5.836,4$. 
como observa o mesmo Pontes DE Miranda, uma conditio iuris que é elemento integrante do tipo legal ou hipótese de incidência normativa ${ }^{20}$. A incerteza da devolução sucessoral ao fideicomissário é tão só de tempo, não do fato em si (eventus incertus quando sed certus an). Juridicamente, o fideicomissário já é herdeiro ou legatário - e, portanto, sucessor do testador —, desde a morte deste. A prova cabal dessa verdade é a norma do art. 1.737 do Código Civil, que os intérpretes brasileiros ainda não assimilaram, em profundidade: como pode, com efeito, o fideicomissário responder pelos encargos da herança que oinda restam, quando vem a assumi-la, se não é sucessor do testador?

Mas, de fato, essa concepção simples e límpida do instituto só é facilmente aceita pela doutrina alemã ${ }^{21}$, graças ao rigor técnico da redação dos textos sobre o fideicomisso, no BGB. Não somente se distinguem, como ainda se separam em capítulos distintos, o substituto sucessoral (Ersatzerbe, §§ 2.096 a 2.099) do fideicomissário ou "pós-herdeiro" (Nacherbe, $\S \S 2.100$ e segs.). Na dúvida, estatui o Código (§ 2.102), interpreta-se a nomeação testamentária como substituição, não como fideicomisso.

No fideicomisso, portanto, há sucessão simultânea, de eficácia consecutiva. Fiduciário e fideicomissário sucedem ao mesmo tempo, mas assumem a herança ou o legado um após o outro.

Como conseqüência lógica, deve-se reconhecer que o fideicomissário, antes de assumir a herança ou o legado, não tem mera expectativa (spes debitum iri) ou um direito eventual, no sentido do disposto no art. 121 do Código Civil, mas direitos

20. “Tratado", cit., § $5.820,11$.

21. cf. Theodor Kipp, Helmut CoIng, Derecho de Succesiones, trad. de Roca Sastre, vol. 1. ${ }^{\circ}, 2 .^{\mathrm{a}}$ ed., Barcelona (Bosch), s/d, págs. 443 e 454; cf. também Palandt Bürgerliches Gesetzbuch, cit., pág. 1792, com ampla bibliografia.

A exposição de motivos do Código Civil suíço, como informa PaUl Piotet (Traité de Droit Privé Suisse, t. IV, Droit Successoral, Ed. Universitaires, Friburgo, 1975, § 20, pág. 95), declarou que la position de l'appelé est anormale en ce qu'il acquiert de fait la succession comme héritier du grevé et qu'en droit on le considère comme un héritier du disposant. Piotet reconhece que, segundo a opinião dominante na Suíça, o fideicomissário sucede o testador, mas afirma que há aí simples questão de terminologia, para concluir: l'appelé est donc un successeur du disposant par l'intermédiaire du grevé, au second degré.

Na Itália, Mario Talamanca sustenta que o fideicomissário é herdeiro do testador e sucessor do fiduciário, mas a título singular (Commentario del Codice Civile a cura di Antonio Scialoja e Giuseppe Branca, Successioni Testamentarie, Bolonha e Roma, reimpressão atualizada da primeira edição, 1978, págs. 387/388). 
subjetivos já plenamente adquiridos, embora de eficácia protraída ${ }^{22}$. Pode, assim, não apenas exercer atos conservatórios, mas exigir as inscrições e averbações de registro em seu nome, como autônomo titular, que é, desses direitos.

Por isso mesmo, a posição jurídica do fiduciário não é apenas de titularidade resolúvel dos bens da herança, mas também de conservação desse patrimônio em vista do seu destino, que é a passagem para o fideicomissário. Esse elemento de fidúcia é essencial à caracterização do instituto, não lhe podendo ser retirado sem que o fideicomisso seja degradado à situação de simples propriedade resolúvel (Código Civil, arts. 647 e 648) ${ }^{23}$. Desde as origens romanas, o fideicomisso tem sido concebido como uma disposição de bens em confiança àquele que, por primeiro, vem à sucessão (fidei tuae committo). A exigência da mais completa boa fé pesa, portanto, sobre o fiduciário, na gestão dos bens fideicomitidos, devendo ele abster-se de praticar qualquer ato que possa, ainda que remotamente, prejudicar o fideicomissário. Sem dúvida, o fiduciário administra bens próprios e não alheios, ao contrário do usufrutuário. Mas administra-os com destinação certa, que é a sua transferência à posse do fideicomissário. Não é, portanto, o fiduciário, em hipótese alguma, um proprietário absoluto, se

22. Na doutrina germânica fala-se, de fato, em “direitos expectativos" (Anwartschaftsrechten). Mas LARENZ adverte que nem toda expectativa jurídica pode ser considerada um "direito expectativo", somente assumindo esse caráter aquela que já apresenta um tal grau de firmeza que aparece, no comércio jurídico, como uma posição patrimonial atual (eine bereits gegenwärtige Vermögensposition), suscetível de alienação e penhora (op. cit., pág. 236). Parece óbvio, nessas condições, que um direito subjetivo desse tipo nada tem que ver com uma simples expectativa.

$\mathrm{Na}$ França, fala-se em “direito eventual", mas a jurisprudência admite que o fideicomissário institua hipotecas sobre os imóveis fideicomitidos (cf. RIPERT e BOUlanger, cit., t. IV, n. ${ }^{0} 1245$ e 1246).

23. cf. Pontes de Miruanda, "Tratado de Direito Privado", cit., t. LVIII, $\S 5.833,8$ e 9 ; KIPP e CoING, cit., pág. 468. A doutrina italiana rejeita, unanimemente, o caráter de fidúcia no fideicomisso (cf. Mario TAlamanca, op. cit., págs. 267/268, com ampla citação bibliográfica). Mas ela se refere não à posse e propriedade em boa fé, no interesse alheio e, sim, à chamada "disposição fiduciária' do art. 627 do Código Civil de 1942, segundo a qual non è ammessa azione in giudizio per accertare che le disposizioni fatte a favore di persona dichiarata nel testamento sono soltanto apparenti e che in realtà riguardano altra persona, anche se espressioni del testamento possono indicare o far presumere che si tratta di persona interposta. Como salientou Angelo Carlo Pelosi (La Proprietà Risolubile nella Teoria del Negozio Condizionato, Milão, Giuffrè, 1975, págs. 184/185), l'obbligo di conservare, sancito dall'art. 692, al. $10^{\circ}$ e 2. , cod. civ., riecheggia chiaramente il principio enunciato in materia di condizione dall'art. 1358 cod. civ., secondo cui il titolare del diritto "risolubile" deve "comportarsi secondo buona fede per conservare integre le ragioni dell'altra parte". 
é que ainda se pode falar, hoje, em absolutismo do direito de propriedade. Ele administra bens não apenas em seu interesse exclusivo, ou egoisticamente, como dizem os alemães (eigennützig), mas também no interesse do fideicomissário, que já é titular desse patrimônio especial, embora temporariamente despojado de eficácia jurídica; isto é, em termos concretos, sem posse.

Esse elemento de fidúcia tempera e corrige o poder do fiduciário de alienar os bens fideicomitidos. O Código Civil brasileiro não tem, a esse respeito, a disposição cautelar do Código Civil italiano (art. 694), fonte de dispositivo análogo no Código Civil português, determinando que a alienação ou oneração só possa fazer-se mediante alvará judicial, em caso de evidente necessidade ou nulidade para o patrimônio fideicomitido. Tampouco contempla a proibição de alienações gratuitas, como está no Código Civil alemão ( $\$ 2.113$, segunda alínea). Mas tais normas podem se considerar implícitas na lei brasileira, pois resultam, necessariamente, tanto dos princípios cardeais que regem o instituto, quanto da própria definição legal dos direitos do fiduciário como propriedade restrita e resolúvel (Código Civil, art. 1.734) ${ }^{24}$.

É, aliás, altamente duvidoso que em nosso direito ainda se admitam as disposições testamentárias instituidoras de um fideicomisso de residuo ou de eo quod supererit ${ }^{25}$. Como salienta MÁRIo TALAMANCA, a faculdade reconhecida ao fiduciário de devolver ao fideicomissário somente o que restar da fortuna fideicomitida caracterizaria autêntica condição potestativa ${ }^{26}$. No direito romano, de resto, o instituto não foi criado sob o signo da arbitrariedade, pois esse tipo de fideicomisso comportava sempre, a partir do período clássico, uma caução garantidora, reconhecendo-se que o fiduciário deveria comportar-se, como administrador, segundo o arbitrium boni viri ${ }^{27}$

Não se trata, pois, apenas de aplicar, em nosso direito, o disposto no art. 647 do Código Civil, que disciplina a trans-

24. Sobre a proibição de alienações gratuitas dos bens fideicomitidos no direito brasileiro, cf. o que escreveu PONTES DE MIRanda, op. cit., t. LVIII, $\S$ 5.836, 6, “d”, pág. 185.

25. Pontes DE Miranda reconhece o caráter "anormal" do instituto (op. cit., t. LVIII, § 5.836, 20.

26. pp. 332/333. Esse tipo de fideicomisso é admitido na França, exatamente porque constitui uma exceção à proibição geral consubstanciada no art. 896 do Código Napoleão.

27. cf. Vincenzo Arangro-Ruiz, Istituzioni di Diritto Romano, op. cit., pág. 576 . 
ferência da coisa objeto de propriedade resolúvel. Ainda é preciso que a alienação ou a oneração dos bens fideicomitidos se revelem necessárias e úteis à preservação da substância patrimonial dos bens objeto de fideicomisso.

Fere-se, aí, ponto de magna importância para a compreensão do mecanismo jurídico do instituto. Vejamos.

Os bens fideicomitidos, seja em herança, seja em legado, não se consideram como coisas singulares, mas formam uma universalidade de direitos e obrigações, um patrimônio separado no patrimônio geral do fiduciário ${ }^{28}$. De um lado, os direitos herdados ou legados não se confundem com os demais elementos ativos do patrimônio do fiduciário, porque afetados pela cláusula fideicomissária. De outro lado, há dívidas ou encargos que podem ser transmitidas pelo de cujus aos seus sucessores (fiduciário e fideicomissário), débitos esses cuja responsabilidade vai até o montante dos ativos sucedidos, em aplicação do princípio do art. 1.587 do Código Civil. Há também obrigações reais ou propter rem, que gravam os bens herdados, ainda que nascidas após a sucessão, as quais, da mesma forma, passam para o fideicomissário.

Ora, em matéria de coisas universais ou coletividades, vigora sempre o princípio do art. 56 do Código Civil, ou seja, à coisa individual se sub-roga o respectivo valor, e vice-versa. Por conseguinte, vendido um bem fideicomitido, a ele se sub-roga, automaticamente, o preço respectivo, no patrimônio separado a ser transmitido ao fideicomissário.

Há mais, porém. O fiduciário tem o dever legal de conservar a substância dos bens que lhe foram confiados pelo testador, ainda que se lhe reconheça o poder de aliená-los ou onerá-los. Essa substância, na verdade, nem sempre se conserva pela aplicação da regra da sub-rogação legal acima referida. Pode suceder que os bens fideicomitidos sejam infungíveis e destinados a uma única utilidade ou finalidade econômica, geralmente declarada pelo testador, de tal sorte que a sub-rogação do preço na coisa não significa obediência ao princípio de preservação da substância dos bens.

Sobre isto, a doutrina é absolutamente concorde, aqui como alhures. "A herança ou parte da herança fideicomitida trata-se como patrimônio (universalidade de direito) ou bens

28. Daí por que são excluídos da comunhão conjugal (Código Civil, art. 263, III). 
destinados a certo fim. Não só quanto ao valor como quanto à substância. Para o fiduciário vale o preceito: uti frui salva substantia rerum. Os bens do fideicomisso, como unidade, devem ir ao fideicomissário, sem alterações substanciais: consideram-se e zelam-se como organismo vivo", escreveu PonTES DE Miranda ${ }^{29}$. E prossegue: "Daí. ou se trate de patrimônio, ou de coisa singular afeta a um destino, dar-se, nos casos ordinários, a sub-rogação; porém, como a substância, no fideicomisso, interessa ao fideicomissário, deve este ser ouvido em todos os atos de mudança, troca ou alienação do todo ou parte dos bens fideicomitidos" (grifos no original).

Para Theodor Kipp e Helmut CoIng, a idéia fundamental do instituto, no Código Civil alemão, é que o fiduciário, embora receba os bens como proprietário, deve conservá-los de forma a entregar a sua substância ao fideicomissário. Sua posição jurídica, portanto, sob esse aspecto, é semelhante à de um usufrutuário, embora sob configuração especial ${ }^{30}$.

$\mathrm{Na}$ doutrina suíça, PAUL PIOTET, comentando o disposto nos arts. 488, primeira alínea e 491, segunda alínea, do Código Civil helvético, observa: L'obligation de "rendre la succession" signifie le devoir de faire en sorte que l'appelé acquière le patrimoine spécial dans un état résultant d'une bonne administration destinée à en conserver la substance ${ }^{31}$.

Ora, essa substância econômica do patrimônio fideicomitido é apreendida em função da finalidade ou utilidade dos bens que compõem essa universalidade. Tratando-se de ações de sociedade anônima, o intérprete não pode deixar de indagar qual a posição sócio-econômica que o testador objetivou transmitir em fideicomisso. Desejou transferir, simplesmente, um capital rentável, ou quis preservar uma posição de mando ou controle empresarial? É óbvio que, na primeira hipótese, é possível e mesmo aconselhável, por vezes, substituir as ações fideicomitidas por outras, que apresentem rentabilidade maior. $\mathrm{Na}$ segunda hipótese, porém, não só deve o fiduciário abster-se de qualquer alienação, como está proibido, sob pena de grave infração ao princípio de boa fé, de aproveitar-se da situação de titularidade temporária das ações, para a apropriar-se do controle empresarial, de modo a esvaziar a fortuna, que lhe foi confiada, de sua verdadeira substância econômica.

29. Tratado de Direito Privado, cit., t. LVIII, § 5.836, 12.

30. Derecho de Succesiones, cit., pág. 444.

31. Traité de Droit Privé Suisse, cit., t. IV, § 20. 


\section{Direito de Preferência Oriundo de Ações em Fideicomisso}

Uma vez explicitada a natureza do chamado direito de preferência à subscrição de ações como valor de capital, e bem compreendidos os princípios fundamentais da instituição fideicomissária, no tocante à preservação da substância do patrimônio em causa, é relativamente fácil demonstrar que às ações subscritas pelo fiduciário, no exercício da opção inerente às primitivas ações fideicomitidas, estende-se, logicamente, o vínculo do fideicomisso.

Tal conclusão é corroborada por respeitáveis opiniões, tanto na doutrina alemã ${ }^{32}$, quanto na italiana ${ }^{33}$, sem que se possa colher, no estrangeiro, nenhuma tomada de posição discrepante.

No direito brasileiro, a única objeção levantada funda-se no teor da norma constante do art. $171, \S 5 .^{\circ}$ da lei de sociedades por ações. Mas essa objeção, na verdade, não se assenta em sólida razão jurídica; provém, antes, de uma superficial leitura do texto e denota assinalada ignorância do mecanismo próprio dos títulos de crédito.

Com efeito, o que a lei acionária regula, no dispositivo mencionado, é a ordem de legitimação para o exercício da opção, não a extensão da titularidade sobre as ações subscritas. Em outras palavras, nas hipóteses de usufruto e fideicomisso concorrência de direitos sobre as mesmas ações - a lei diz quem pode e quando pode subscrever; mas, obviamente, não altera em nada o regime de direito comum de usufruto e fideicomisso, relativamente às ações subscritas ${ }^{34}$. Sobre essa questão,

32. KIPP e CoIng sublinham que se trata de mera aplicação do princípio de que pertence, naturalmente, ao patrimônio fideicomitido, tudo o que o fiduciário adquire com base em direito integrante daquele patrimônio (op. cit., § 49, II, I, pág. 468). Comentando o $§ 186$ da lei de sociedades por ações alemã de 1965, o qual regula o direito de opção à subscrição de novas ações, GodiN e WILHELMI escrevem: "Pelo fideicomisso, está o fiduciário autorizado (a subscrever); o produto (da cessão) do direito de opção ou as novas ações pertencem, no entanto, ao patrimônio fideicomitido". No original: Bei Vorerbschaft ist der Vorerbe berechtigt; der Erlös für das Bezugsrecht die neue Aktie gehört aber zur Erbmasse (Aktiengesetz, t. II, 4. ${ }^{\mathrm{a}}$ ed., De Gruyter, Berlim, e Nova Iorque, 1971, pág. 1122).

33. MÁrio TAlamanga observa que a emissão de novas ações, sejam elas bonificadas ou subscritas, acarreta sempre uma diminuição do valor das ações primitivas, de que derivam. Em conseqüência, le azioni cosi acquistate cadranno in proprietà dell'erede fiduciario, ma saranno sottoposte al vincolo fedecommissario (op. cit., pág. 361).

34. "As novas ações, em caso de direito de opção", escreveu PonTEs DE Miranda, "não são frutos; são proveito que ocorreu, por existir o direito de opção, razão por que a lei brasileira somente cogitou da legitimação a subscrever, 
o art. $171, \S 5 .^{\circ}$ da Lei n. $^{\circ} 6.404$ não é de nenhum auxílio pàra 0 intérprete.

A ação de sociedade anônima, como todo título de crédito, exerce, fundamentalmente, uma função de legitimação de exercício de direitos e assunção de obrigações e responsabilidades, perante a companhia. A posse legitimada das ações indica quem está autorizado a agir perante a sociedade - quer exercendo direitos, quer fazendo atuar poderes - e quem responde pelo cumprimento das obrigações e deveres societários, notadamente a integralização das próprias ações. Mas essa mesma posse legitimada não prejulga a verdadeira titularidade da posição acionária. O portador legitimado das ações recebe dividendos ou retira certificados de ações bonificadas, subscreve novas ações de aumento de capital ou manifesta-se em dissidência pedindo o recesso. À companhia não interessa saber (nem está ela autorizada a indagar) se, de fato, tais ações pertencem ao portador legitimado que exerce tais direitos e poderes, ou se ele age no interesse de outrem proprietário ou sócio oculto.

É por isso mesmo que o legislador brasileiro, desde 1940 , referindo-se à chamada "propriedade" das ações, restringe o alcance das normas editadas ao terreno das presunções. "A propriedade das ações nominativas presume-se pela inscrição do nome do acionista no livro de "Registro das Ações Nominativas" (Lei n. ${ }^{\circ} 6.404$, art. 31). "A propriedade das ações endossáveis presume-se pela posse do título com base em série regular de endossos" (art. 32). "O detentor presume-se proprietário das ações ao portador" (art. 33). Essa presunção de propriedade é suficiente para fundar a certeza legitimatória.

A contrario sensu, se o verdadeiro proprietário das ações não consegue realizar as condições de legitimação acionária porque perdeu os certificados ao portador, não obteve a inscrição de seu nome no livro "Registro das Ações Nominativas", ou não o fez averbar no livro "Registro das Ações Endossáveis" - ficará radicalmente impossibilitado de agir contra a sociedade ou dentro dela (em assembléias gerais, por exemplo).

a optar" (op. cit., t. L, § 5.329, 5, pág. 361). E SÁNCHEZ ANdRÉs, referindo-se ao direito de opção na hipótese de usufruto: las normas mercantiles resuelven ciertamente el problema de la disponibilidad del derecho frente a la sociedad, pero no los del goce en las relaciones internas entre usufructuario y nuda proprietario (op. cit., pág. 408). 
Nas ações endossáveis, aliás, essa dissociação entre titularidade e legitimação, possível em todo título de crédito, é claramente afirmada em lei. O último endossatário de uma série regular de endosso é presumido proprietário, "mas o exercício de direitos perante a companhia requer a averbação do nome do acionista" no livro competente (art. 32). Vale dizer: aquele cujo nome continua averbado nos registros societários é o único legitimado a exercer direitos perante a companhia, não obstante já haver, por hipótese, endossado os certificados acionários, deixando, portanto, de ser "proprietário".

Análoga dissociação ocorre nas hipóteses de concorrência de direitos sobre as mesmas ações, quer se trate de condomínio acionário, quer se cuide de direitos reais de garantia ou de gozo, quer se estabeleça a sucessão fideicomissária. Perante a companhia, somente um dos titulares de direitos sobre a ação, ou o representante da coisa comum, é legitimado a agir. "Quando a ação pertencer a mais de uma pessoa", dispõe o art. 28, parágrafo único da Lei n. ${ }^{\circ}$ 6.404, "os direitos por ela conferidos serão exercidos pelo representante do condomínio". É caso, pois, de representação necessária e não, simplesmente, facultativa, pois aos condôminos não se permite agir conjuntamente, nas relações com a sociedade anônima. Terão que designar quem os represente.

Nas hipóteses de direitos reais sobre ações alheias, da mesma forma, não há legitimação conjunta dos titulares de direitos, para o exercício do voto. Só um pode votar, sem prejuízo dos direitos do outro ou dos outros (arts. 113 e 114).

Em suma, objeto das normas próprias da lei de sociedades por ações é, tão-somente, a legitimação para o exercício dos direitos e poderes no âmbito societário, pois é só isso que interessa ao funcionamento da companhia. A relação jurídica que o acionista mantenha com terceiros, no tocante às suas ações, é objeto de outra regulação legal, estranha ao direito das sociedades anônimas. As normas de legitimação do exercício de direitos acionários não implicam, de modo algum, que a parte legitimada possa exercer seus direitos e poderes em seu exclusivo interesse, nem que essa legitimação autorize, como frisou ASCARELLI, "uma alteração, ainda que indireta, do alcance dos direitos patrimoniais dos outros titulares de direitos reais sobre a ação" ${ }^{35}$.

A razão suprema dessa origem reside no princípio da indivisibilidade da ação em relação à companhia (Lei n. ${ }^{\circ} 6.404$,

35. Saggi di Diritto Commerciale, Milão (Giuffrè), 1955, pág. 231. 
art. 28). A rigor, ainda seria possível admitir uma divisibilidade no exercício de direitos de crédito perante a sociedade, como o direito ao dividendo. Mas seria logicamente impossível cogitar de uma divisibilidade na atuação de poderes. Ninguém pode exercer meio voto, ou um quarto de fiscalização. .

Voltando, agora, à norma do art. $171, \S 5 .^{\circ}$ da lei de sociedades por ações, parece fácil compreender que o seu alcance restringe-se à mera questão de legitimação no exercício do chamado direito de preferência. $\mathrm{Na}$ concorrência de direitos entre nu-proprietário e usufrutuário, ou entre fiduciário e fideicomissário, a lei apenas indica quem está autorizado a exercer esse poder e em que momento. No direito anterior, a regulação dessa ordem de legitimação era criticável, pois limitando-se o Decreto-lei n. 2.627 a declarar que "o direito de preferência, se não exercido pelo acionista, poderá sê-lo pelo usufrutuário ou fideicomissário", fazia perdurar a incerteza até o último dia do prazo do exercício da opção. A lei nova, corrigindo essa imperfeição, veio impedir que o nu-proprietário e o fiduciário exerçam a opção no último decêndio do prazo geral de subscrição, reservando esses derradeiros dez dias para o usufrutuário e o fideicomissário.

0 fato de o texto legal referir-se ao fiduciário como "acionista" não tem outro significado senão o de marcar uma posição de legitimação perante a sociedade. É ele acionista, mas não deixa, por isso, de ser fiduciário; assim como acionistas podem ser também, os menores, os interditos, as fundações ou o próprio Estado, cada qual investido de um status jurídico próprio. Não é pelo fato de ser acionista que o menor se torna plenamente capaz ou que o Estado deixa de ser uma pessoa jurídica de direito público interno, com todas as limitações e prerrogativas que esse status comporta.

Se a lei coloca o fiduciário junto com o nu-proprietário para o exercício do direito de subscrição, na primeira parte do prazo legal, e os denomina ambos "acionistas", é, simplesmente, porque nessas duas posições jurídicas existe a propriedadé. Mas a semelhança se esgota aí, pois, tal como o usufrutuário perante o nu-proprietário, o fiduciário tem o dever legal de preservar a substância do bem possuído, respeitando os direitos de fideicomissário. Sob esse aspecto, como já frisamos, o fiduciário se aproxima do usufrutuário, embora sob configuração especial. E é exatamente por isso que o regime legal das ações subscritas difere, fundamentalmente, entre fiduciário e nu-proprietário. Este, ao subscrever, salvo estipulação em contrário do ato de instituição do usufruto, adquire as ações novas 
sem restrições, porque elas integram o seu capital. O fiduciário, ao revés, devendo preservar o capital recebido, para devolvê-lo, íntegro, ao fideicomissário, não pode se apropriar das ações subscritas, oriundas das que recebeu em confiança, separando-as, em proveito próprio, do capital fideicomitido.

É, aliás, muito discutível que o fiduciário possa ceder o seu direito de opção. PonTes DE MIRANDA entende que sim, embora ressaltando que "se o fiduciário cede o direito de subscrever, ou algo recebe pela renúncia, tem de empregá-lo como produto do bem fideicomitido" ${ }^{36}$. Trata-se, provavelmente, de opinião colhida em autores estrangeiros ${ }^{37}$, mas que não parece se afeiçoar ao nosso regime jurídico específico. Com efeito, estabelecendo a lei brasileira um prazo exclusivo de subscrição, nos últimos dez dias, ao usufrutuário e ao fideicomissário, não se vê bem com que fundamento poderiam o nu-proprietário e o fiduciário frustrar, por ato próprio, o exercício desse direito exclusivo, antes do prazo ${ }^{38}$.

Seja como for, diante do princípio de que o capital fideicomitido deve ser preservado em sua substância, é totalmente desprezível a opinião nominalista, segundo a qual o fiduciário só está obrigado a conservar o mesmo número de ações que recebeu em fideicomisso. Se assim fora, em primeiro lugar, não se explicaria, racionalmente, porque a lei manda, de modo expresso, que às ações distribuídas em bonificação se estenda o vínculo do fideicomisso (Lei $n .^{\circ}$ 6.404, art. 169, $\S 2 .^{\circ}$ ). Ademais, quando se fala em substância de uma coletividade, segundo o princípio geral que disciplina as coisas universais (Código Civil, art. 56), tem-se em mira, obviamente, o seu valor intrínseco e não a sua mera expressão formal. "Na coletividade, fica sub-rogado ao indivíduo o respectivo valor". Não é preciso invocar a distinção entre dívidas de dinheiro e dívidas de valor, nem tampouco lembrar a parábola evangélica dos talentos, para saber que, se o testador deixa em fideicomisso determinada quantia de dinheiro, o fiduciário cometeria grave desrespeito ao dever legal de preservação da substância do bem, caso se limitasse, vários anos após a sucessão, a devolver ao fideicomissário a mesma quantia monetária; sobretudo num

36. op. cit., t. L, $\S 5.329,5$, pág. 364 .

37. cf., por exemplo, na Itália, Mario Talamanca, op. cit., pág. 361 , nota 5.

38. Miranda VÀlverde, na vigência do Decreto-lei n. ${ }^{\circ} 2.627$, negava ao fiduciário o direito de ceder o direito de subscrição: "Sociedades por Açōes", 3. ed., Rio de Janeiro, Ed. Forense, 1959, II, n..$^{\circ} 580$. 
país como o nosso, cuja moeda vive, há décadas, no regime de invejável estabilidade que todos conhecemos.

De resto, a discussão sobre essa matéria é quase ociosa, diante da norma constante do art. 1.736 do Código Civil brasileiro. Se o fideicomissário, aceitando a herança, tem direito à parte, que, ao fiduciário, em qualquer tempo, acrescer, não se podem distrair do patrimônio fideicomitido as ações novas, por aquele geradas, ainda que subscritas pelo fiduciário. Note-se que a lei não distingue entre acréscimos naturais e voluntários. Já frisamos que o direito de opção à subscrição de novas ações não é fruto e, sim, acréscimo das ações, pois que se trata de parte que, ao fiduciário, em qualquer tempo, acrescer, não se reduz-lhe a substância. Se se quisesse raciocinar analogicamente, poder-se-ia comparar esse direito de subscrição, uma vez exercido, a uma espécie de benfeitoria necessária, tendo por finalidade conservar o valor da coisa (Código Civil, art. $\left.62, \S 3 .^{\circ}\right)$. Ora, as benfeitorias necessárias aderem à coisa benfeitoriada, como o acessório adere ao principal. 0 máximo que poderia pretender o fiduciário, que exerce a opção de subscrever novas ações, seria, na devolução do capital acionário ao fideicomissário, uma indenização pelo que pagou ao subscrever, consoante a regra geral do art. 516 do Código Civil ${ }^{39}$.

39. Comentando o art. 1.736 do Código Civil, Clóvis Bevilaqua emite uma opinião contraditória, que não merece acolhida. Declara que "os melhoramentos que o fiduciário introduzir nos bens gravados, desde que não sejam despesas ordinárias de administração no sentido mais largo da palavra, não se transferem ao fideicomissário, que os terá de indenizar, ou, melhor, que serão deduzidos na herança, quando forem benfeitorias necessárias e úteis, e trouxerem aumento efetivo e atual ao valor dos bens" (op. cit., vol. 6, pág. 162). Em primeiro lugar, se trata de benfeitorias necessárias, elas não trazem "aumento efetivo e atual ao valor dos bens", mas apenas o conservam ou evitam sua deterioração. Ademais, cuidando-se de benfeitorias, não há por que “deduzí-las" da herança, como se fossem coisas principais ou autônomas. 